\title{
Variations in egg characteristics of ruffe Gymnocephalus cernua inhabiting brackish and freshwater environments
}

\author{
Roland Svirgsden $^{1} \cdot$ Anu Albert $^{1} \cdot$ Mehis Rohtla $^{1} \cdot$ Imre Taal $^{1} \cdot$ Lauri Saks $^{1}$. \\ Aare Verliin $^{1} \cdot$ Martin Kesler $^{1} \cdot$ Kalvi Hubel $^{1} \cdot$ Markus Vetemaa $^{1}$. \\ Toomas Saat ${ }^{1}$
}

Received: 15 September 2014/Revised: 5 May 2015/Accepted: 11 May 2015/Published online: 22 May 2015

(C) Springer-Verlag Berlin Heidelberg and AWI 2015

\begin{abstract}
Egg characteristics of teleost fishes are affected by various abiotic and biotic factors. In order to reproduce successfully, freshwater fishes inhabiting brackish environments must alter their reproductive characteristics, including egg properties, to increased osmotic pressure. Ruffe Gymnocephalus cernua was used as a model species to compare egg characteristics between fish populations inhabiting brackish and freshwater environments. Fish from the brackish environment had larger eggs with higher energy content than the individuals originating from freshwater. In freshwater, eggs from the first batch were larger than from the second. Female size correlated positively with egg size in the brackish water population. In freshwater, this correlation was evident only with eggs from the first batch. Only a weak positive correlation was found between fish condition and egg size in females from the brackish water population. Egg size variation did not differ between sites, nor was it correlated with mean egg size or any other maternal traits within populations. These results indicate significant modifications in reproductive strategies between brackish and freshwater ruffe populations. Additionally, results show that at least in freshwater, the first batch of eggs is of the highest quality and therefore more important for reproduction.
\end{abstract}

Communicated by H.-D. Franke.

Roland Svirgsden

roland.svirgsden@ut.ee

1 Estonian Marine Institute, University of Tartu, Vanemuise 46A, 51014 Tartu, Estonia
Keywords Oocyte size $\cdot$ Salinity $\cdot$ Reproduction strategy · Energy content $\cdot$ Batch spawning - Sibling size variation

\section{Introduction}

Size of teleost egg varies at the species, population and individual level (Chambers and Leggett 1996; Albert et al. 2006; Gregersen et al. 2006, 2009). Many studies (especially on salmonids) have shown that larger and older females produce larger eggs (e.g., Bagenal 1969; Kennedy et al. 2007; Quinn et al. 2011), but this is not a universal phenomenon (Fuiman and Trojnar 1980; Iguchi and Yamaguchi 1994). Some studies have shown that female age also influences the chemical composition of the egg matter (e.g., Kamler 2005). Environmental factors (e.g., salinity, temperature and $\mathrm{pH}$ ) may have significant effects on egg properties (Brooks et al. 1997; Bownds et al. 2010). For example, due to lower salinity and osmotic pressure in the brackish Baltic Sea several marine fish species produce eggs that are more buoyant and have higher water content compared with their oceanic counterparts (Solemdal 1967; Nissling et al. 1994; Thorsen et al. 1996). On the other hand, osmotic pressure is significantly higher in brackish environments than in freshwater and that is the reason why some freshwater fishes have low fry survival rate in the Baltic Sea (Tibblin et al. 2012). Also biological interactions like predation (Segers and Taborsky 2012) and competition (McCormick 2006) influence egg size. Additionally, females in better physiological condition have been shown to produce larger and heavier eggs (Ojanguren et al. 1996; Donelson et al. 2009). Furthermore, egg energy content has been shown to be positively affected by female condition and size (Heinimaa and Heinimaa 2004; Ouellet 
et al. 2001). At large, different habitats have certain sets of factors that affect egg quality and different egg properties are favoured in specific environments.

A general rule is that bigger eggs give rise to bigger offspring (Bagenal 1969; Einum and Fleming 2000; Bownds et al. 2010), but there are some exceptions (Lagomarsino et al. 1988). Larger offspring have many advantages over smaller conspecifics: They are more resistant to starvation because of larger yolk reserves (Rideout et al. 2005), have greater swimming speed for catching prey and escaping predators (Ojanguren et al. 1996; Segers and Taborsky 2011), take fewer behavioral risks (Segers and Taborsky 2011), have generally faster growth rates (Wallace and Aasjord 1984) and outgrow their gape-size-limited predators faster (Sogard 1997). Also, large offspring are better adapted to extreme environmental conditions (Alcaraz and Garcia-Berthou 2007; Riesch et al. 2012) and have greater probability to live through their first winter (Braaten and Guy 2004; Hurst 2007). However, while scarce, there are some examples where larger eggs have disadvantages over smaller ones: In some cases, larger eggs have greater mortality rates at higher temperatures (Régnier et al. 2013) and certain predators may positively discriminate for bigger larvae (Litvak and Leggett 1992). In benign environments, where food is plentiful and competition rarely occurs, larger offspring have little or no survival advantages (Hutchings 1991; Gisbert et al. 2000; Rideout et al. 2005; Segers and Taborsky 2011). When females produce large eggs in environments where size has no effect on survival, it will have reduced fitness (in terms of lost fecundity) due to trade-offs between egg size and fecundity while selection is thought to act largely to maximize maternal fitness only (Smith and Fretwell 1974; Elgar 1990). Furthermore, there is some evidence that the bet-hedging strategy in egg size is employed when future environmental conditions are increasingly variable and unpredictable (Marshall et al. 2008; Morrongiello et al. 2012).

Ruffe Gymnocephalus cernua is a small benthophagous percid fish species. Its native distribution range is in temperate zones of Europe and Northern Asia, but it has been introduced into the Great Lakes in North America and some European lakes where ruffe naturally did not exist (Simon and Vondruska 1991; Pratt et al. 1992; Winfield et al. 1996; Ogle 1998). Ruffe is a typical batch spawner (usually up to three batches during one spawning season) with high total fecundity (Neja 1988; Ogle 1998; Saat et al. 2003; Lorenzoni et al. 2009). It can tolerate a wide range of environmental and ecological factors. For example, ruffe can inhabit lakes with low productivity and $\mathrm{pH}$ as well as eutrophicated brackish bays (Mäemets 1977; Saat et al. 2003). In Estonia, it inhabits over 150 lakes and many lowland rivers, but it is also abundant in the coastal waters of the Baltic Sea (Saat et al. 2003). This makes ruffe a suitable model species for salinity studies.

There are reasons to assume that significant modifications exist in reproductive strategies between freshwater and brackish water ruffe populations. Albert et al. (2006) studied eggs from one freshwater and two brackish water sites and found that the egg diameters of brackish water populations were significantly greater than the egg diameter of freshwater population. To expand upon this study, we analyze in this study the variability of multiple egg characteristics in wild-caught ruffe inhabiting freshwater (FW) and brackish water (BW) environments. More specifically, we study if these size differences between populations are only attributed to the greater water volume or are the dry matter content also greater in BW environments. Further, we also evaluate how egg traits are affected by maternal size and age and if those relationships are consistent or not between different populations and biomes.

\section{Materials and methods}

\section{Study sites}

Fish were collected from one brackish water and two freshwater sites: Pärnu Bay, Lake Peipsi and Lake Saadjärv (Fig. 1). Pärnu Bay is situated in the northeastern part of Gulf of Riga, Baltic Sea. It is a semi-enclosed bay with a surface area of approximately $700 \mathrm{~km}^{2}$ and volume of $2 \mathrm{~km}^{3}$. The inner part of the bay is relatively shallow (average 5-6 m), but depth gradually increases toward southwestern parts (max depth $25 \mathrm{~m}$ ). Salinity varies usually between $3.5-6$ ppt. The hydrological conditions of the bay are mainly formed under the influence of river discharge (chiefly Pärnu River) and water exchange with the open part of the Gulf of Riga. The bay is affected by human-induced eutrophication (Kotta et al. 2004). The study site was situated in the inner part of the bay, where ruffe are found throughout the area and are locally very abundant.

Lake Peipsi is a large (Europe's fourth largest, $3555 \mathrm{~km}^{2}$ ) shallow lowland lake. The study site was situated in the shallow $(1.5 \mathrm{~m})$ near-shore area of the largest part of the lake (Lake Peipsi s.s.) with surface area of $2611 \mathrm{~km}^{2}$ and average depth of $8.3 \mathrm{~m}(\max 12.9 \mathrm{~m})(\mathrm{Jaani}$ 2001). Ruffe are abundant throughout this eutrophic lake (Saat et al. 2003).

Lake Saadjärv is situated between drumlins in the eastern part of Estonia. It has a surface area of $7.08 \mathrm{~km}^{2}$, maximum depth of $25 \mathrm{~m}$ (average $8 \mathrm{~m}$ ), limited catchment area and slow water exchange rate. This mesotrophic lake is characterized by strong water stratification and high water transparency (Mäemets 1977). Ruffe are mostly 
Fig. 1 Location map of the study sites. Square indicates brackish and circles freshwater sites

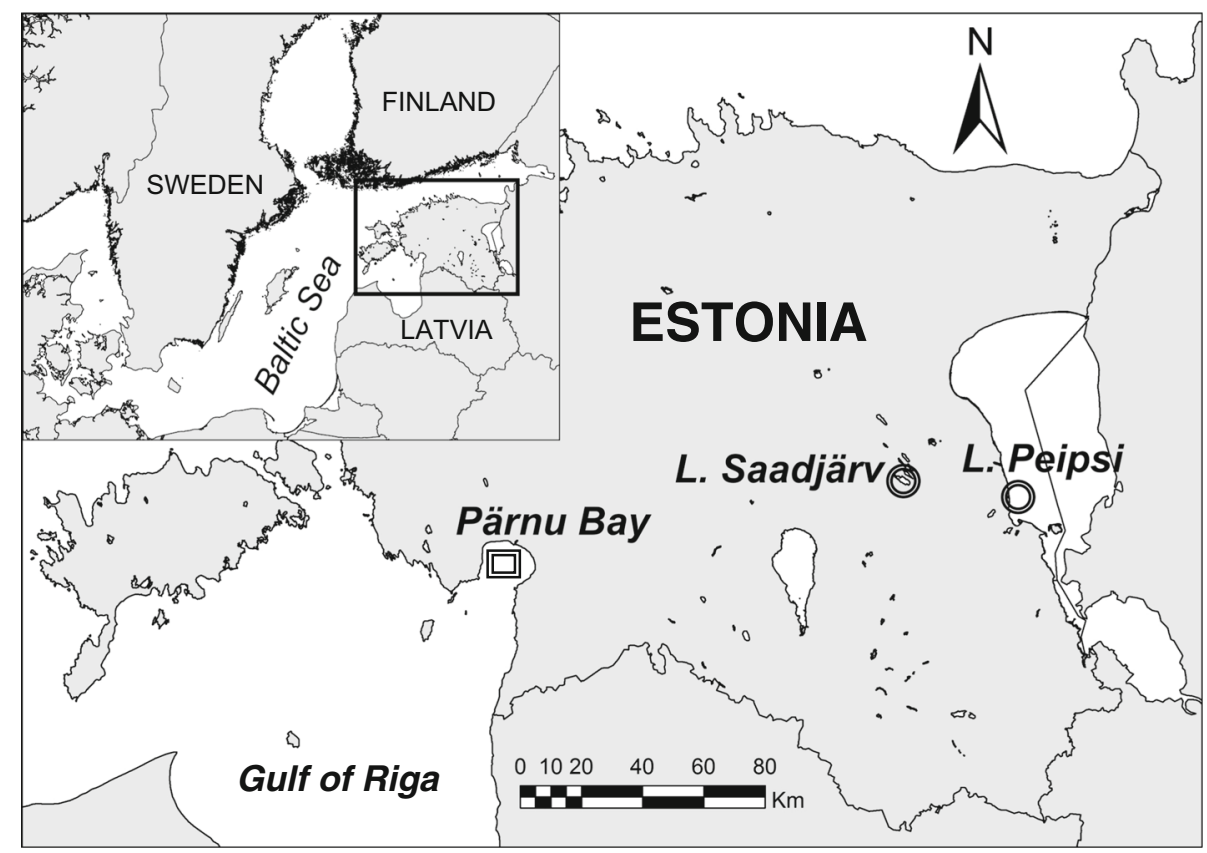

found in deeper $(>10 \mathrm{~m})$ zones of the lake. The study site was situated in the deeper $(10-12 \mathrm{~m})$ southern part of the lake.

\section{Fish sampling and processing}

Fish were caught by stationary gillnets. Sampling was done in 2011 on the following dates: May 11th, 27th and June 6th at Lake Saadjärv ( $N=21,10$ and 12 , respectively); May 17-18th at Lake Peipsi $(N=31)$; June 2-4th at Pärnu Bay $(N=42)$. Only females with "running" gametes were used in the analyses (altogether 116 specimens). The fish were killed immediately after capture by severing the central nervous system. In the laboratory, total length (TL, to the nearest $1 \mathrm{~mm}$ ) and weight (TW, to the nearest $0.1 \mathrm{~g}$ ) were measured. A sample of ovulated eggs was stripped from each fish for further analysis. Remaining gonads and rest of the internal organs were removed from body cavity, and somatic weight (SW, $0.1 \mathrm{~g}$ ) was recorded. General condition index (Fulton's condition factor $K$ ) was calculated using the following formula $K=100,000\left(\mathrm{SW} / \mathrm{TL}^{3}\right)$, where SW is in grams and TL in millimeters (Bolger and Connolly 1989). Sagittal otoliths were used for age determination. Otoliths were embedded in epoxy resin, and transverse sections through the core were obtained with the diamond saw (IsoMet ${ }^{\circledR}$ Low Speed Saw, Buehler Ltd.). The surface of the cross sections was polished with fine particle abrasive paper (grit size P4000). Cross sections were stained for about $15 \mathrm{~min}$ in a solution of neutral red $(1 \%)$ and acetic acid $(0.5 \%)$ in distilled water (Richter and McDermott 1990). Age was determined by counting the narrow dark red bands (winter zones) under a stereomicroscope against dark and light background. Two readers read the otoliths, and the percentage of agreement was determined $(89 \%)$.

\section{Egg size measurements and analysis}

Stripped eggs from ovulating fish were divided into two subsamples (one for diameter analyses and the other for weight analyses). The diameter subsample was preserved in $1 \%$ buffered formaldehyde. This is considered the lowest possible concentration that would ensure proper oocyte preservation while minimizing changes in oocyte size (Lowerre-Barbieri and Barbieri 1993). Before diameter measurements, eggs were washed in tap water and photographed under the stereomicroscope (SZX10, Olympus Corporation). Egg cross-sectional area was measured from the photograph (approximately 250 oocytes per fish) using ImageJ software (National Institutes of Health). Eggs were generally circularly shaped, and diameter $(D)$ was calculated from area $(A)$ using simple circle area formula: $D=2 \sqrt{ }(A / \pi)$. Sibling size variation (SSV) within each female was estimated as the coefficient of variation $(\mathrm{CV}, y)$ of egg diameter $(y=100 \sigma / \bar{x}$, where $\bar{x}$ is the mean and $\sigma$ is $\mathrm{SD}$ ).

The second subsample was photographed on a Petri dish, then weighted (wet weight) and subsequently frozen for later dry weight analysis. Subsamples were dried in the oven at $60^{\circ} \mathrm{C}$ for $48 \mathrm{~h}$ and weighted for the second time (dry weight). The number of eggs in the subsample was counted from the photograph, and mean egg wet weight and dry weight were calculated as wet weight and dry 
weight of the subsample divided by the number of eggs in that subsample. Egg dry matter percentage was calculated as egg dry weight divided by wet weight. The total energy content of dried egg mass (dried weight subsample) was determined with a bomb calorimeter (IKA C 5000, IKA ${ }^{\circledR}$ Werke GmbH \& Co. KG) and expressed as egg mass energy content $(\mathrm{kJ} / \mathrm{g}$, dry mass) and mean energy content per egg ( $\mathrm{J}$, calculated from mean egg dry weight and egg mass energy content).

Egg size parameters (diameter, wet weight and dry weight) indicated that the fish caught at Lake Saadjärv on May 11th likely had their first batch of eggs and fish caught on May 27th and June 6th had probably their second batch (Table 1). Furthermore, sampling attempts in Lake Saadjärv were not limited to the dates given above, but on the other dates no females with running gametes were caught. Therefore, fish from Lake Saadjärv were considered as two different groups (first and second batches, hereafter referred as Saadjärv I and Saadjärv II) in statistical analyses.

All the statistical analyses were conducted using STATISTICA 7.0 (Statsoft Inc.). One-way ANOVA was used to compare egg characteristics between populations, followed by Tukey HSD post hoc test. Pearson correlation (when data were normally distributed) and Spearman correlation were used to detect relationships between maternal traits and egg properties. Although multiple statistical tests were conducted, no Bonferroni-type adjustments to the $P$ value were made. Bonferroni adjustments are overly conservative (drastically reduce statistical power), especially for the ecological field data and the cases where tests are interrelated (Perneger 1998; Moran 2003; Nakagawa 2004).

\section{Results}

There were significant differences in egg wet weight $\left(F_{3,112}=263.8, P<0.001\right.$; Fig. $\left.2 \mathrm{a}\right)$, dry weight $\left(F_{3,112}=\right.$ 322.9, $P<0.001$; Fig. 2 b) and diameter $\left(F_{3,112}=413.5\right.$, $P<0.001$; Fig. 2c), with eggs of the brackish water fish being heavier and larger than those of the freshwater. Egg dry matter percentage $\left(F_{3,112}=104.1, P<0.001\right.$; Fig. $\left.2 \mathrm{~d}\right)$ and egg mass energy content $\left(F_{3,35}=9.6, P<0.001\right.$; Fig. 2e) were highest in the brackish water and Saadjärv I fish. Egg energy content was highest in Pärnu Bay population which is largely attributed to the greater egg size in brackish water $\left(F_{3,35}=86.8, P<0.001\right.$; Fig. $\left.2 \mathrm{f}\right)$. Also fish condition varied among the sites $\left(F_{3,112}=48.4\right.$, $P<0.001$; Fig. $2 \mathrm{~g}$ ), but sibling size variation differed only between Lake Peipsi and Lake Saadjärv II $\left(F_{3,111}=4.5\right.$, $P<0.005$; Fig. 2h). The first and the second batch of ruffe eggs in Lake Saadjärv differed significantly in all measured egg characteristics (Fig. 2a-f), with eggs from the first batch being larger and energy denser than eggs from the second batch. The ranges and means for total lengths, conditions and egg characteristics of ruffe from the freshwater and the brackish water sites are given in Table 2.

Total length (TL) was positively correlated with egg size measurements (diameter, wet weight and dry weight) in Pärnu and Saadjärv I fish, but not in Peipsi and Saadjärv II (Table 3). Furthermore, graphic analyses hint that the smaller ruffe in Pärnu do not exhibit a positive trend between egg and body size as the larger conspecifics do (Fig. 3a, b). Egg mass energy content was positively correlated with TL only in Saadjärv II, but egg energy content was positively correlated in Pärnu and Saadjärv I (largely attributed to egg size correlation with TL; Fig. 3c). Negative relationship between TL and fish condition was found only in Peipsi. Due to the inherent correlation between TL and age, relationships between age and egg parameters were almost identical to those with TL (Table 3; Fig. 3d). A weak positive correlation was found between age and condition in Pärnu but not in the other sites.

Egg wet weight correlated negatively with its dry matter percent in Peipsi and Saadjärv I (Fig. 3e), whereas egg dry weight and dry matter percent were positively correlated in Pärnu (Table 3). Strong correlations were found between egg wet/dry weight and diameter (Fig. 3f), but nevertheless egg diameter did not correlate with egg dry matter percent.
Table 1 One-way ANOVA results for comparison of egg size parameters of ruffe caught from Lake Saadjärv on different dates

\begin{tabular}{llllll}
\hline Egg size parameter & Date & $N$ & Mean \pm SD & $F_{2,40}$ & $P$ \\
\hline Diameter (mm) & 11 May & 21 & $0.913 \pm 0.036^{\mathrm{a}}$ & 39.89 & $<0.001$ \\
& 27 May & 10 & $0.838 \pm 0.024^{\mathrm{b}}$ & & \\
6 June & 12 & $0.825 \pm 0.023^{\mathrm{b}}$ & & \\
Wet weight (mg) & 11 May & 21 & $0.357 \pm 0.051^{\mathrm{a}}$ & 14.70 & $<0.001$ \\
& 27 May & 10 & $0.304 \pm 0.045^{\mathrm{b}}$ & & \\
Dry weight (mg) & 6 June & 12 & $0.271 \pm 0.030^{\mathrm{b}}$ & & $<0.001$ \\
& 11 May & 21 & $0.118 \pm 0.015^{\mathrm{a}}$ & 36.87 & \\
& 27 May & 10 & $0.087 \pm 0.015^{\mathrm{b}}$ & & \\
\hline
\end{tabular}

Different letters in superscript indicate differences in egg size parameters within the respective one-way model (Tukey HSD test $P<0.05$ ) 

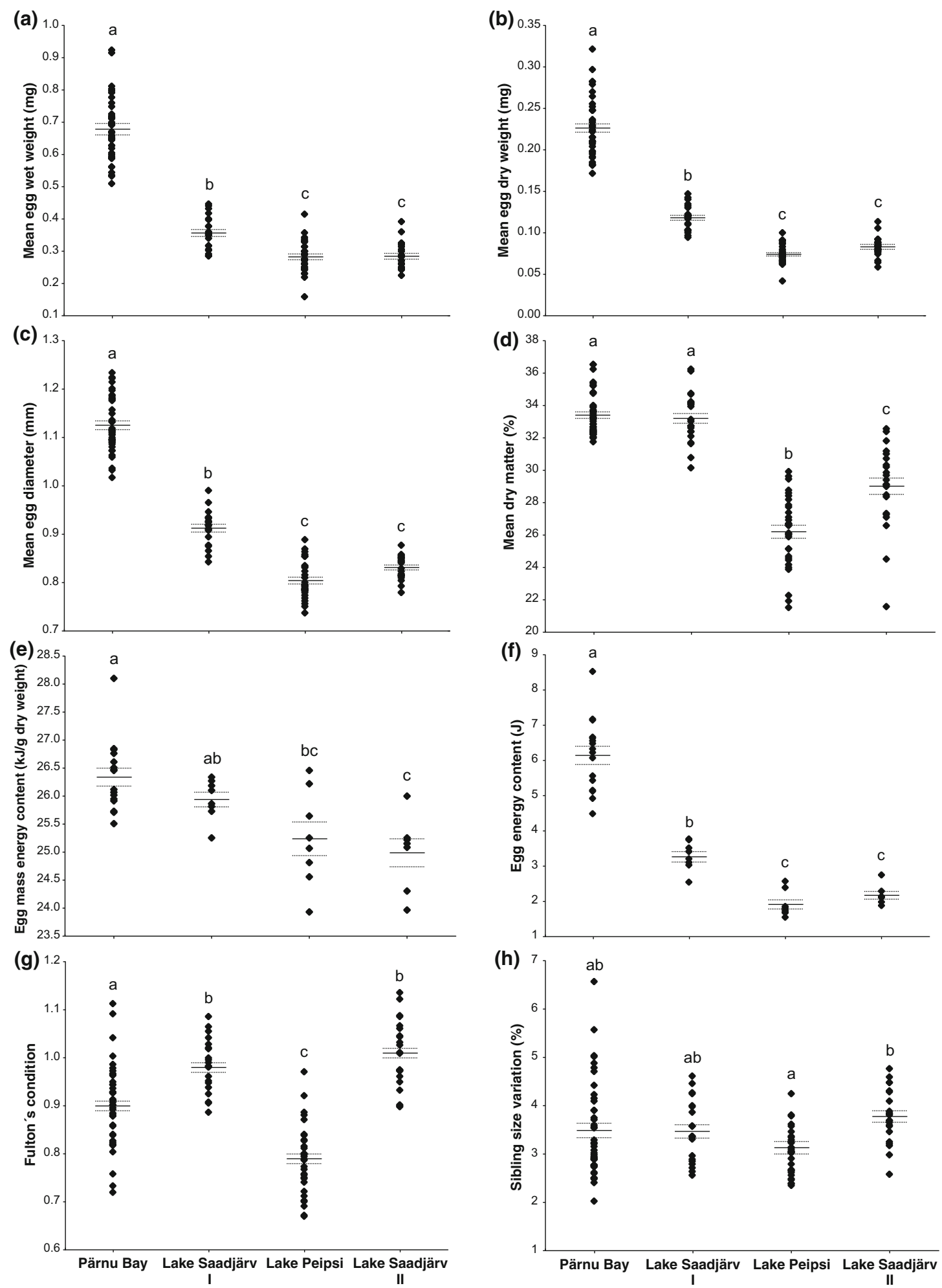

Fig. 2 Differences in egg wet weight (a), dry weight (b), diameter (c), percentage of dry matter (d), egg mass energy content (e), egg energy content (f), fish condition (g) and sibling size variation (h) of one brackish water (Pärnu Bay) and two freshwater (Lakes Saadjärv and Peipsi) ruffe populations and between first (I; caught on May
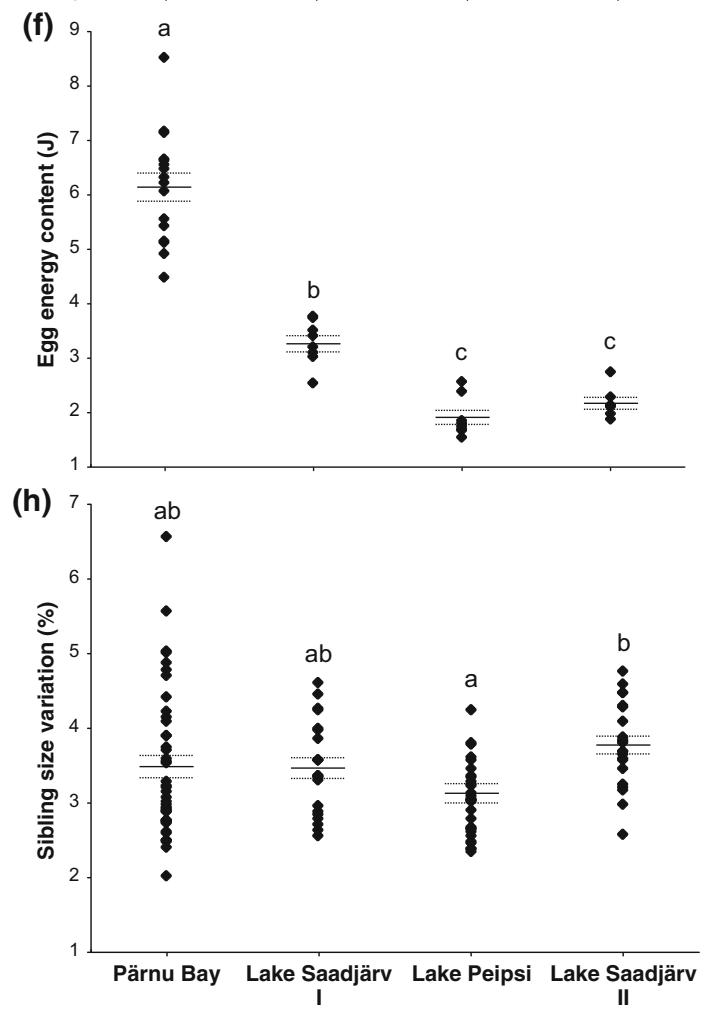

11th) and second (II; caught on May 27th and June 6th) batch of eggs from Lake Saadjärv. Solid lines represent means and dashed lines SE. Different letters indicate differences in egg properties and fish condition within the respective one-way model (Tukey HSD test $P<0.05)$ 
None of the egg size measurements correlated with egg mass energy content.

Fish condition did not correlate with egg size indicators (except for a weak positive relationship with egg dry weight in Pärnu, Table 3) nor with egg and egg mass energy content. No significant correlations were found between sibling size variation and measured egg characteristics, fish TL or condition.

\section{Discussion}

In our study, we found considerable differences in egg characteristics between the freshwater $(\mathrm{FW})$ and the brackish water (BW) ruffe populations. In general, ruffe from BW produced larger (diameter) and heavier (wet weight) eggs. In brackish Pärnu Bay, eggs had approximately twice as high dry weight values compared with the eggs from FW. These findings show that larger egg size of BW ruffe is not only due to greater water volume, but the eggs contain more dry matter (most probably yolk lipids and proteins) than their FW conspecifics. This result suggests that larger eggs may be an adaption to increased salinity in BW environments. There is a trade-off between egg size and fecundity: Fish that produce larger offspring lose in their overall fecundity and thereby in their potential maternal fitness (Smith and Fretwell 1974; Elgar 1990; Lobon-Cervia et al. 1997). Because of that, either larger offspring (from larger eggs) must have greater fitness and survival in BW to compensate mother's greater energetic investment per offspring (coupled with loss in fecundity) or larger eggs are physiologically crucial at the certain embryonic developmental stages for successful reproduction in saline environment. Previous studies have found that ruffe embryos from BW populations have increased salinity tolerance compared with FW populations (Vetemaa and Saat 1996; Albert et al. 2006). Results from these studies give us the reasons to believe that larger egg size of BW ruffe is indeed physiologically crucial for successful reproduction in BW environments. Alternatively, larger eggs in BW may be evolved in response to predator pressure from small fish like Gobiidae that are absent in FW. Common goby Pomatoschistus minutus and sand goby Pomatoschistus microps have been shown to feed on small fish eggs and larvae (Ojaveer 2003; Zloch and Sapota 2010), but larger eggs and larger larvae hatched from them may be out of the threat due to small gape size of the gobies.

In Lake Saadjärv (FW), eggs from the first batch were larger than from the second. This is in accordance with the general rule that egg size of batch spawners diminishes in consecutive batches as the spawning season progresses (Buckley et al. 1991; Hsiao et al. 1994; Nguyen et al. 2012). Albert et al. (2006) found that although there was a decrease in ruffe egg diameter for FW population, no such trends were found in BW populations as the breeding season continued. In the coastal areas of the NE Baltic Sea and larger lakes, ruffe spawning usually starts in April (Saat et al. 2003). Based on water temperature and period of the year, fish from Pärnu Bay (caught at the beginning of June) were presumably ready to spawn their second or even third batch of eggs. Also sampling time (in the middle of May) and egg characteristics (compared with Lake Saadjärv) indicate that the fish from Lake Peipsi were spawning their second batch of eggs. Interestingly, FW first but not

Table 2 Total length and egg characteristics of ruffe collected from one brackish water (Pärnu) and two freshwater (Saadjärv and Peipsi) sites

\begin{tabular}{lllllllll}
\hline Site & TL $(\mathrm{mm})$ & $\begin{array}{l}\text { Fish } \\
\text { condition }\end{array}$ & $\begin{array}{l}\text { Egg diameter } \\
(\mathrm{mm})\end{array}$ & $\begin{array}{l}\text { Egg wet weight } \\
(\mathrm{mg})\end{array}$ & $\begin{array}{l}\text { Egg dry weight } \\
(\mathrm{mg})\end{array}$ & $\begin{array}{l}\text { Egg dry } \\
\text { matter }(\%)\end{array}$ & $\begin{array}{l}\text { Egg mass energy } \\
(\mathrm{kJ} / \mathrm{g})\end{array}$ & $\begin{array}{l}\text { Egg energy } \\
(\mathrm{J})\end{array}$ \\
\hline Pärnu Bay & $189 \pm 21$ & $0.90 \pm 0.08$ & $1.125 \pm 0.055$ & $0.676 \pm 0.095$ & $0.226 \pm 0.035$ & $34.4 \pm 1.3$ & $26.34 \pm 0.63$ & $6.15 \pm 1.02$ \\
& $124-233$ & $0.72-1.11$ & $1.016-1.233$ & $0.508-0.923$ & $0.171-0.321$ & $31.7-36.5$ & $25.51-28.10$ & $4.47-8.52$ \\
& $N=42$ & $N=42$ & $N=42$ & $N=42$ & $N=42$ & $N=42$ & $N=16$ & $N=16$ \\
Lake & $97 \pm 10$ & $0.98 \pm 0.05$ & $0.913 \pm 0.036$ & $0.357 \pm 0.051$ & $0.118 \pm 0.015$ & $33.2 \pm 1.6$ & $25.94 \pm 0.36$ & $3.29 \pm 0.41$ \\
Saadjärv I & $80-115$ & $0.89-1.08$ & $0.842-0.990$ & $0.284-0.446$ & $0.094-0.146$ & $30.1-36.2$ & $25.25-26.34$ & $2.53-3.77$ \\
& $N=21$ & $N=21$ & $N=21$ & $N=21$ & $N=21$ & $N=21$ & $N=8$ & $N=8$ \\
Lake & $110 \pm 9$ & $1.01 \pm 0.07$ & $0.831 \pm 0.024$ & $0.286 \pm 0.040$ & $0.083 \pm 0.012$ & $29.0 \pm 2.6$ & $24.99 \pm 0.67$ & $2.17 \pm 0.28$ \\
Saadjärv & $92-125$ & $0.90-1.35$ & $0.779-0.876$ & $0.225-0.390$ & $0.059-0.113$ & $21.7-32.5$ & $23.96-26.00$ \\
II & $N=22$ & $N=22$ & $N=22$ & $N=22$ & $N=22$ & $N=22$ & $N=7$ \\
Lake Peipsi & $150 \pm 16$ & $0.79 \pm 0.07$ & $0.804 \pm 0.038$ & $0.284 \pm 0.049$ & $0.074 \pm 0.011$ & $26.2 \pm 2.2$ & $25.24 \pm 0.84$ \\
& $109-168$ & $0.67-0.97$ & $0.736-0.888$ & $0.157-0.414$ & $0.042-0.100$ & $21.5-29.9$ & $23.93-26.45$ & $1.91 \pm 0.36$ \\
& $N=31$ & $N=31$ & $N=31$ & $N=31$ & $N=31$ & $N=31$ & $N=8$ & $N=8$ \\
\hline
\end{tabular}

Lake Saadjärv I and II denote the first and the second batch of eggs. Values are given as mean \pm SD and range 
Table 3 Correlations between different egg and fish characteristics

\begin{tabular}{|c|c|c|c|c|}
\hline Correlation & Population & $\begin{array}{l}\text { Correlation } \\
\text { coefficient }\end{array}$ & $N$ & $P$ \\
\hline \multirow[t]{4}{*}{$\mathrm{TL} \times$ mean egg diameter } & Pärnu & 0.457 & 42 & 0.002 \\
\hline & Saadjärv I & 0.670 & 21 & $<0.001$ \\
\hline & Saadjärv II & -0.113 & 22 & ns \\
\hline & Peipsi & $0.093^{\mathrm{a}}$ & 31 & ns \\
\hline \multirow[t]{4}{*}{$\mathrm{TL} \times$ mean egg wet weight } & Pärnu & 0.576 & 42 & $<0.001$ \\
\hline & Saadjärv I & 0.536 & 21 & 0.012 \\
\hline & Saadjärv II & 0.355 & 22 & ns \\
\hline & Peipsi & $0.187^{\mathrm{a}}$ & 31 & ns \\
\hline \multirow[t]{4}{*}{$\mathrm{TL} \times$ mean egg dry weight } & Pärnu & 0.546 & 42 & $<0.001$ \\
\hline & Saadjärv I & 0.538 & 21 & 0.012 \\
\hline & Saadjärv II & 0.279 & 22 & ns \\
\hline & Peipsi & $0.001^{\mathrm{a}}$ & 31 & $\mathrm{~ns}$ \\
\hline \multirow{4}{*}{$\begin{array}{l}\text { TL } \times \text { egg mass energy } \\
\text { content }\end{array}$} & Pärnu & -0.354 & 16 & ns \\
\hline & Saadjärv I & 0.873 & 8 & 0.005 \\
\hline & Saadjärv II & 0.375 & 7 & ns \\
\hline & Peipsi & $-0.310^{\mathrm{a}}$ & 8 & ns \\
\hline \multirow[t]{4}{*}{$\mathrm{TL} \times$ egg energy content } & Pärnu & 0.558 & 16 & 0.025 \\
\hline & Saadjärv I & 0.763 & 8 & 0.028 \\
\hline & Saadjärv II & 0.170 & 7 & ns \\
\hline & Peipsi & $0.405^{\mathrm{a}}$ & 8 & ns \\
\hline \multirow[t]{4}{*}{$\mathrm{TL} \times$ fish condition } & Pärnu & 0.065 & 42 & ns \\
\hline & Saadjärv I & -0.030 & 21 & ns \\
\hline & Saadjärv II & 0.001 & 22 & ns \\
\hline & Peipsi & $-0.451^{\mathrm{a}}$ & 31 & 0.011 \\
\hline \multirow[t]{5}{*}{$\mathrm{TL} \times$ age } & Pärnu & $0.634^{\mathrm{a}}$ & 42 & $<0.001$ \\
\hline & Saadjärv I & $0.751^{\mathrm{a}}$ & 21 & $<0.001$ \\
\hline & Saadjärv II & $0.618^{\mathrm{a}}$ & 22 & 0.002 \\
\hline & Peipsi & $0.625^{\mathrm{a}}$ & 31 & $<0.001$ \\
\hline & Combined & $0.747^{\mathrm{a}}$ & 116 & $<0.001$ \\
\hline \multirow[t]{4}{*}{ Age $\times$ mean egg diameter } & Pärnu & $0.368^{\mathrm{a}}$ & 42 & 0.016 \\
\hline & Saadjärv I & $0.701^{\mathrm{a}}$ & 21 & $<0.001$ \\
\hline & Saadjärv II & $0.138^{\mathrm{a}}$ & 22 & ns \\
\hline & Peipsi & $-0.019^{\mathrm{a}}$ & 31 & ns \\
\hline \multirow[t]{4}{*}{ Age $\times$ mean egg wet weight } & Pärnu & $0.541^{\mathrm{a}}$ & 42 & $<0.001$ \\
\hline & Saadjärv I & $0.533^{\mathrm{a}}$ & 21 & 0.013 \\
\hline & Saadjärv II & $0.412^{\mathrm{a}}$ & 22 & $\mathrm{~ns}$ \\
\hline & Peipsi & $0.284^{\mathrm{a}}$ & 31 & ns \\
\hline \multirow[t]{4}{*}{ Age $\times$ mean egg dry weight } & Pärnu & $0.525^{\mathrm{a}}$ & 42 & $<0.001$ \\
\hline & Saadjärv I & $0.592^{\mathrm{a}}$ & 21 & $<0.001$ \\
\hline & Saadjärv II & $0.341^{\mathrm{a}}$ & 22 & ns \\
\hline & Peipsi & $0.004^{\mathrm{a}}$ & 31 & ns \\
\hline \multirow{4}{*}{$\begin{array}{l}\text { Age } \times \text { egg mass energy } \\
\text { content }\end{array}$} & Pärnu & $-0.493^{\mathrm{a}}$ & 16 & ns \\
\hline & Saadjärv I & $0.674^{\mathrm{a}}$ & 8 & ns \\
\hline & Saadjärv II & $0.060^{\mathrm{a}}$ & 7 & ns \\
\hline & Peipsi & $-0.436^{\mathrm{a}}$ & 8 & ns \\
\hline \multirow[t]{4}{*}{ Age $\times$ egg energy content } & Pärnu & $0.451^{\mathrm{a}}$ & 16 & ns \\
\hline & Saadjärv I & $0.784^{\mathrm{a}}$ & 8 & 0.021 \\
\hline & Saadjärv II & $0.139^{\mathrm{a}}$ & 7 & ns \\
\hline & Peipsi & $0.156^{\mathrm{a}}$ & 8 & ns \\
\hline
\end{tabular}

Table 3 continued

\begin{tabular}{|c|c|c|c|c|}
\hline Correlation & Population & $\begin{array}{l}\text { Correlation } \\
\text { coefficient }\end{array}$ & $N$ & $P$ \\
\hline \multirow[t]{4}{*}{ Age $\times$ fish condition } & Pärnu & $0.323^{\mathrm{a}}$ & 42 & 0.037 \\
\hline & Saadjärv I & $-0.028^{\mathrm{a}}$ & 21 & ns \\
\hline & Saadjärv II & $0.104^{\mathrm{a}}$ & 22 & $\mathrm{~ns}$ \\
\hline & Peipsi & $-0.086^{\mathrm{a}}$ & 31 & ns \\
\hline \multirow[t]{5}{*}{ Egg wet weight $\times$ diameter } & Pärnu & 0.822 & 42 & $<0.001$ \\
\hline & Saadjärv I & 0.764 & 21 & $<0.001$ \\
\hline & Saadjärv II & 0.566 & 22 & 0.006 \\
\hline & Peipsi & 0.782 & 31 & $<0.001$ \\
\hline & Combined & 0.969 & 116 & $<0.001$ \\
\hline \multirow{4}{*}{$\begin{array}{l}\text { Egg wet weight } \times \text { dry } \\
\text { matter } \%\end{array}$} & Pärnu & 0.169 & 42 & ns \\
\hline & Saadjärv I & -0.456 & 21 & 0.038 \\
\hline & Saadjärv II & -0.228 & 22 & ns \\
\hline & Peipsi & -0.505 & 31 & 0.004 \\
\hline \multirow[t]{5}{*}{ Egg dry weight $\times$ diameter } & Pärnu & 0.827 & 42 & $<0.001$ \\
\hline & Saadjärv I & 0.858 & 21 & $<0.001$ \\
\hline & Saadjärv II & 0.508 & 22 & 0.016 \\
\hline & Peipsi & 0.848 & 31 & $<0.001$ \\
\hline & Combined & 0.979 & 116 & $<0.001$ \\
\hline \multirow{4}{*}{$\begin{array}{l}\text { Egg dry weight } \times \text { dry } \\
\text { matter } \%\end{array}$} & Pärnu & 0.425 & 42 & 0.005 \\
\hline & Saadjärv I & -0.153 & 21 & ns \\
\hline & Saadjärv II & 0.371 & 22 & ns \\
\hline & Peipsi & 0.025 & 31 & ns \\
\hline \multirow{4}{*}{$\begin{array}{l}\text { Fish condition } \times \text { egg dry } \\
\text { weight }\end{array}$} & Pärnu & 0.324 & 42 & 0.036 \\
\hline & Saadjärv I & -0.195 & 21 & $\mathrm{~ns}$ \\
\hline & Saadjärv II & -0.161 & 22 & ns \\
\hline & Peipsi & 0.071 & 31 & $\mathrm{~ns}$ \\
\hline \multirow{4}{*}{$\begin{array}{l}\text { Fish condition } \times \text { egg mass } \\
\text { energy content }\end{array}$} & Pärnu & -0.387 & 16 & ns \\
\hline & Saadjärv I & 0.372 & 8 & $\mathrm{~ns}$ \\
\hline & Saadjärv II & 0.390 & 7 & $\mathrm{~ns}$ \\
\hline & Peipsi & 0.028 & 8 & $\mathrm{~ns}$ \\
\hline \multirow{4}{*}{$\begin{array}{l}\text { Sibling size variation } \times \text { egg } \\
\text { diameter }\end{array}$} & Pärnu & 0.187 & 42 & ns \\
\hline & Saadjärv I & 0.118 & 21 & $\mathrm{~ns}$ \\
\hline & Saadjärv II & -0.122 & 22 & $\mathrm{~ns}$ \\
\hline & Peipsi & -0.032 & 31 & $\mathrm{~ns}$ \\
\hline
\end{tabular}

$n s$ not significant

a Spearman's rank correlation coefficient (otherwise Pearson's correlation coefficient)

the second batch shared many similar characteristics with BW eggs (except the overall size). Both groups of eggs (BW and FW first) had higher dry matter percentage and egg mass energy content (although latter in Lake Saadjärv's first and second batches were statistically inseparable) compared with FW second batch. Also, female size affected positively egg size in BW and FW first batch eggs, but not in FW second batches. All these data indicate that the eggs from the first batch are of the highest quality at least in FW and therefore more important for successful reproduction. Eggs from the second batch have higher 

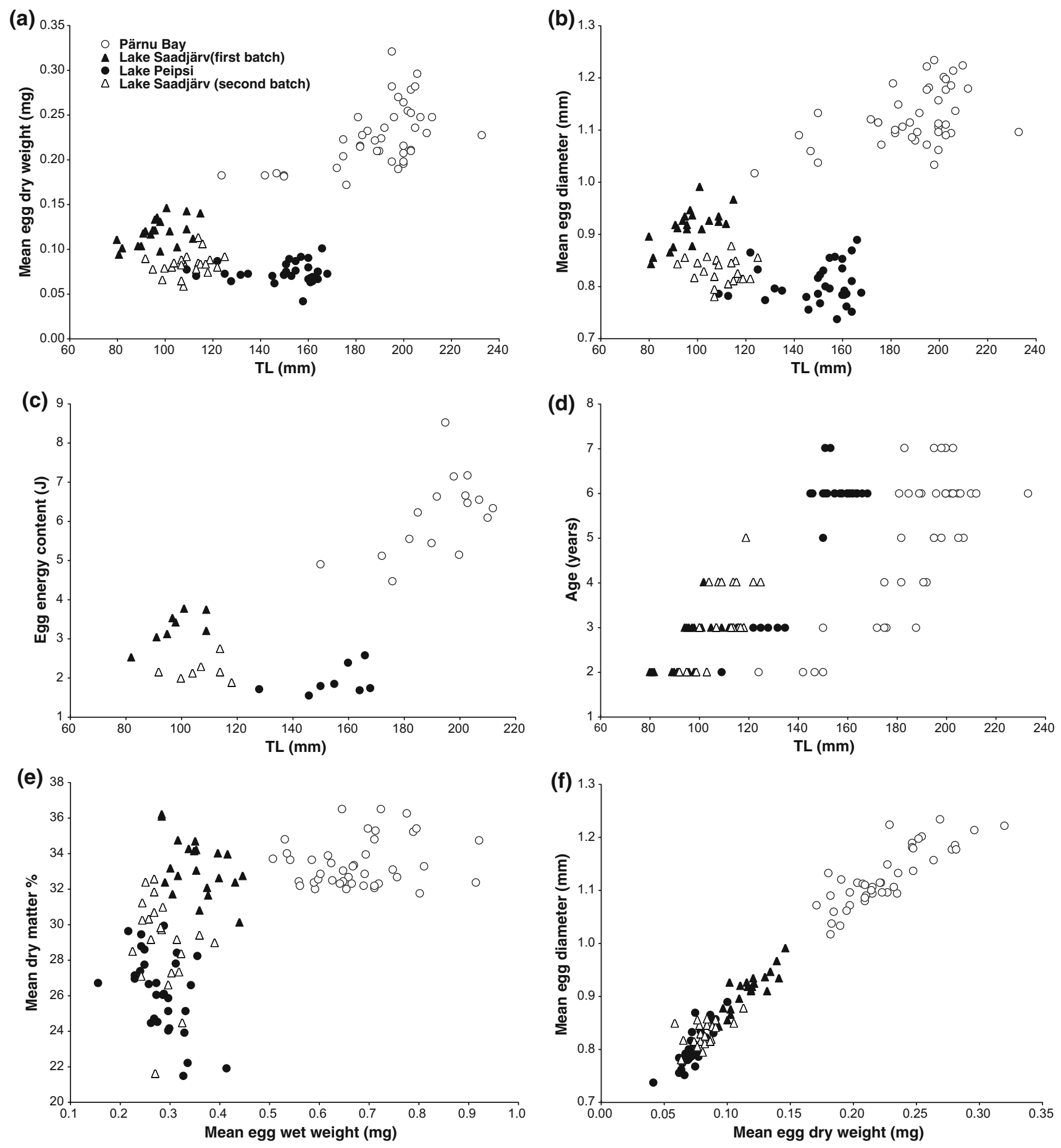

Fig. 3 Correlations between fish total length (TL) and egg dry weight (a), TL and egg diameter (b), TL and egg energy content (c), TL and fish age (d), egg wet weight and percentage of dry matter (e), egg dry weight and diameter (f) in two freshwater (Lakes Saadjärv and Peipsi)

water content and are not associated with the females' individual size and physiological condition. This may be the result of depletion of females' energy reserves as demonstrated in some species (Kjesbu et al. 1991; Rideout et al. 2005). In the littoral zone and estuaries of the Baltic Sea,

and one brackish water (Pärnu Bay) ruffe populations. Open circle Pärnu Bay; filled triangle Lake Saadjärv (first batch); filled circle Lake Peipsi; open triangle Lake Saadjärv (second batch)

ruffe demonstrates higher growth rates compared with FW lakes due to ample food supply (Saat et al. 2003) and that may be the reason why ruffe in BW maintain positive relationship between female size and egg size throughout the spawning season. Our data also imply that smaller females 
in BW do not retain this relationship, but sample size was not adequate to make decisive conclusions.

Besides egg characteristics, the age and growth profiles also differed between the studied ruffe populations (Fig. 3d), which could potentially influence our results. In Lake Saadjärv (mesotrophic), spawning fish were smallest and youngest, while in Lake Peipsi (eutrophic) fish were considerably larger and older, but the egg characteristics were very similar between those two sites. Somatic condition of fish was highest in Lake Saadjärv and lowest in Lake Peipsi. Significant differences in the egg properties also existed between the fish from BW and Lake Peipsi, despite similar age composition and growth characteristics of these two populations. All these data imply that the egg size differences between the FW and BW fish cannot solely be explained by abundant food supply and faster growth rates. Furthermore, these data give us the confidence to believe that fish size distribution differences among sites do not significantly influence our finding that ruffe eggs in BW are considerably larger than in FW. Ouellet et al. (2001) found that female pre-spawning condition of Atlantic cod Gadus morhua was positively correlated with egg dry weight. They also showed a positive relationship between condition of female and hatching success. Laine and Rajasilta (1999) found similar results with Atlantic herring Clupea harengus. We found only a weak positive correlation between condition and egg dry weight in BW, while TL had no effect on condition despite being positively correlated with the egg size. Furthermore, female condition had no effect on the egg size in FW. These results indicate that in the case of ruffe, female condition does not play important role in shaping of the egg size.

Srivastava and Brown (1991) proposed that energy content of eggs may be a good egg quality indicator. There is a propensity for the species with larger eggs to have higher egg mass caloric value compared with the species with smaller eggs (Kamler 2005). According to our results, ruffe have higher egg mass caloric value compared with the species with similar egg size (Kamler 2005). Our results demonstrate that the BW ruffe population generally had higher egg mass energy content than the FW populations (although BW and Saadjärv's first batch were statistically inseparable). This may be the result of better food supply in BW. Also, eggs from the first batch in Lake Saadjärv had higher caloric values compared with the eggs from Lake Saadjärv's second batch and Lake Peipsi. This is in accordance with the hypothesis that the first batch of eggs is most important for ruffe and possibly for other batch spawning species. Previous studies have found positive correlations between the egg energy content and fish condition in cod (Ouellet et al. 2001) and between the egg mass energy content and fish size in case of Atlantic salmon Salmo salar (Heinimaa and Heinimaa 2004). In the latter case, however, no relation between the egg diameter and fish size was found. We did not find any correlations between fish condition and egg mass energy content, and TL correlated positively with egg mass energy only in the Lake Saadjärv's first batch. These results indicate that ruffe condition and size have minimal effect on the egg mass energy content levels. However, egg energy content correlated positively with TL in BW and FW first batch which is largely attributable to the positive correlation between TL and egg size. Furthermore, larger fish from the Lake Saadjärv's first batch had higher egg mass energy content. Therefore, in FW, large ruffe produce eggs of high quality with greater energy density and larger size.

Studies on salmonids have found that egg size variation (sibling size variation-SSV) decreases as the mean egg size increases (Koops et al. 2003; Gregersen et al. 2009). Furthermore, SSV has been found to increase as environment becomes less predictable (Koops et al. 2003; Gregersen et al. 2009). We did not find any difference in SSV between the BW and FW ruffe populations nor was SSV correlated with the mean egg size or any other maternal trait within the populations. These findings demonstrate that intrapopulation egg size variation is negligible compared with the differences between the BW and FW populations. Einum and Fleming (2004) concluded that diversified bet hedging (variable-sized offspring) is favoured by selection only in extremely variable environments and even then conservative bet hedging (fewer but larger offspring) would be more advantageous. The results from our study suggest that ruffe does not employ diversified bet hedging in the studied populations. Instead, our data indicate that conservative bet hedging is being employed in the BW environment.

In this study, we did not measure the hormonal content of eggs, but hormone levels could also be different between environments and batches. It has been shown that hormones influence larval development and therefore may affect egg quality (reviewed in Brooks et al. 1997). Hormones have been shown to pass into the fish eggs from the mother's circulation system and may affect the osmoregulation, growth and other physiological functions in developing fish larvae prior to the functional development of their own endocrine glands (Greenblatt et al. 1989; Lam 1994). Questions whether hormonal contents of ruffe eggs vary between different habitats and spawning batches and whether this is associated with other characteristics of egg quality should be investigated in the future.

In conclusion, variation and divergence in egg properties demonstrated in this study indicate significant modifications in reproductive strategies between the BW and FW ruffe populations. These alterations are most probably adaptations to increased osmotic pressure in the BW 
environments. Further studies are needed to determine whether those differences persist when the ruffe of $\mathrm{BW}$ origin are reared in FW and vice versa. Also, additional data are needed to verify whether those trends manifest in the other FW species that inhabit and reproduce in the BW environments (e.g., minnow Phoxinus phoxinus, perch Perca fluviatilis, pike Esox lucius).

Acknowledgments Financial support was provided by Estonian Science Foundation Grant 8281 and target financed Project SF0180005s 10 .

\section{References}

Albert A, Vetemaa M, Saat T (2006) Laboratory-based reproduction success of ruffe, Gymnocephalus cernuus (L.), in brackish water is determined by maternal properties. Ecol Freshw Fish 15:105-110. doi:10.1111/j.1600-0633.2006.00138.x

Alcaraz C, Garcia-Berthou E (2007) Life history variation of invasive mosquitofish (Gambusia holbrooki) along a salinity gradient. Biol Conserv 139:83-92. doi:10.1016/j.biocon.2007.06.006

Bagenal TB (1969) Relationship between egg size and fry survival in brown trout Salmo trutta L. J Fish Biol 1:349-353. doi:10.1111/ j.1095-8649.1969.tb03882.x

Bolger T, Connolly PL (1989) The selection of suitable indexes for the measurement and analysis of fish condition. J Fish Biol 34:171-182. doi:10.1111/j.1095-8649.1989.tb03300.x

Bownds C, Wilson R, Marshall DJ (2010) Why do colder mothers produce larger eggs? An optimality approach. J Exp Biol 213:3796-3801. doi:10.1242/jeb.043356

Braaten PJ, Guy CS (2004) First-year growth, condition, and sizeselective winter mortality of freshwater drum in the lower Missouri River. Trans Am Fish Soc 133:385-398. doi:10.1577/01-136

Brooks S, Tyler CR, Sumpter JP (1997) Egg quality in fish: what makes a good egg? Rev Fish Biol Fish 7:387-416. doi:10.1023/ A: 1018400130692

Buckley LJ, Smigielski AS, Halavik TA, Caldarone EM, Burns BR, Laurence GC (1991) Winter flounder Pseudopleuronectes americanus reproductive success. 2. Effects of spawning time and female size on size, composition and viability of eggs and larvae. Mar Ecol-Prog Ser 74:125-135. doi:10.3354/ meps074125

Chambers RC, Leggett WC (1996) Maternal influences on variation in egg sizes in temperate marine fishes. Am Zool 36:180-196. doi:10.1093/icb/36.2.180

Donelson JM, Munday PL, McCormick MI (2009) Parental effects on offspring life histories: when are they important? Biol Lett 5:262-265. doi:10.1098/rsbl.2008.0642

Einum S, Fleming IA (2000) Highly fecund mothers sacrifice offspring survival to maximize fitness. Nature 405:565-567. doi: $10.1038 / 35014600$

Einum S, Fleming IA (2004) Environmental unpredictability and offspring size: conservative versus diversified bet-hedging. Evol Ecol Res 6:443-455

Elgar MA (1990) Evolutionary compromise between a few large and many small eggs: comparative evidence in teleost fish. Oikos 59:283-287. doi:10.2307/3545546

Fuiman LA, Trojnar JR (1980) Factors affecting egg diameter of white suckers (Catostomus commersoni). Copeia 1980:699-704. doi: $10.2307 / 1444446$

Gisbert E, Williot P, Castelló-Orvay F (2000) Influence of egg size on growth and survival of early stages of Siberian sturgeon
(Acipenser baeri) under small scale hatchery conditions. Aquaculture 183:83-94. doi:10.1016/s0044-8486(99)00287-2

Greenblatt M, Brown C, Lee M, Dauder S, Bern H (1989) Changes in thyroid hormone levels in eggs and larvae and in iodide uptake by eggs of coho and chinook salmon, Oncorhynchus kisutsch and O. tschawytscha. Fish Physiol Biochem 6:261-278. doi:10.1007/ bf01881680

Gregersen F, Haugen TO, Larsen $\emptyset \mathrm{N}$ (2006) Egg size differentiation among sympatric demes of brown trout: possible effects of density-dependent interactions among fry. Ecol Freshw Fish 15:237-246. doi:10.1111/j.1600-0633.2006.00129.x

Gregersen F, Vollestad LA, Olsen EM, Haugen TO (2009) Siblingsize variation in brown trout Salmo trutta in relation to egg size and stream size. J Fish Biol 74:1259-1268. doi:10.1111/j.10958649.2009.02194.x

Heinimaa S, Heinimaa P (2004) Effect of the female size on egg quality and fecundity of the wild Atlantic salmon in the subarctic River Teno. Boreal Environ Res 9:55-62

Hsiao SM, Greeley MS, Wallace RA (1994) Reproductive cycling in female Fundulus heteroclitus. Biol Bull 186:271-284. doi:10. 2307/1542273

Hurst TP (2007) Causes and consequences of winter mortality in fishes. J Fish Biol 71:315-345. doi:10.1111/j.1095-8649.2007.01596.x

Hutchings JA (1991) Fitness consequences of variation in egg size and food abundance in brook trout Salvelinus fontinalis. Evolution 45:1162-1168. doi:10.2307/2409723

Iguchi K, Yamaguchi M (1994) Adaptive significance of inter- and intrapopulational egg size variation in ayu Plecoglossus altivelis (Osmeridae). Copeia 1:184-190

Jaani A (2001) The location, size and general characterisation of Lake Peipsi and its catchment area. In: Nõges T (ed) Lake Peipsi: meteorology, hydrology, hydrochemistry. Sulemees Publishers, Tartu, pp 10-17

Kamler E (2005) Parent-egg-progeny relationships in teleost fishes: an energetics perspective. Rev Fish Biol Fish 15:399-421. doi:10.1007/s11160-006-0002-y

Kennedy J, Geffen AJ, Nash RDM (2007) Maternal influences on egg and larval characteristics of plaice (Pleuronectes platessa L.). J Sea Res 58:65-77. doi:10.1016/j.seares.2007.01.003

Kjesbu OS, Klungsoyr J, Kryvi H, Witthames PR, Walker MG (1991) Fecundity, atresia, and egg size of captive Atlantic cod (Gadus morhua) in relation to proximate body composition. Can J Fish Aquat Sci 48:2333-2343. doi:10.1139/f91-274

Koops MA, Hutchings JA, Adams BK (2003) Environmental predictability and the cost of imperfect information: influences on offspring size variability. Evol Ecol Res 5:29-42

Kotta J, Simm M, Kotta I, Kanošina I, Kallaste K, Raid T (2004) Factors controlling long-term changes of the eutrophicated ecosystem of Pärnu Bay, Gulf of Riga. Hydrobiologia 514:259-268. doi:10.1023/B:hydr.0000018224.56324.44

Lagomarsino IV, Francis RC, Barlow GW (1988) The lack of correlation between size of egg and size of hatchling in the Midas cichlid, Cichlasoma citrinellum. Copeia 1988:1086-1089. doi: $10.2307 / 1445742$

Laine P, Rajasilta M (1999) The hatching success of Baltic herring eggs and its relation to female condition. J Exp Mar Biol Ecol 237:61-73. doi:10.1016/s0022-0981(98)00213-5

Lam TJ (1994) Hormones and egg/larval quality in fish. J World Aquacult Soc 25:2-12. doi:10.1111/j.1749-7345.1994. tb00798.x

Litvak MK, Leggett WC (1992) Age and size-selective predation on larval fishes: the bigger-is-better hypothesis revisited. Mar EcolProg Ser 81:13-24. doi:10.3354/meps081013

Lobon-Cervia J, Utrilla CG, Rincón PA, Amezcua F (1997) Environmentally induced spatio-temporal variations in the fecundity of brown trout Salmo trutta L.: trade-offs between 
egg size and number. Freshw Biol 38:277-288. doi:10.1046/j. 1365-2427.1997.00217.x

Lorenzoni M, Pace R, Pedicillo G, Viali P, Carosi A (2009) Growth, catches and reproductive biology of ruffe Gymnocephalus cernuus in Lake Piediluco (Umbria, Italy). Folia Zool 58:420-435

Lowerre-Barbieri SK, Barbieri LR (1993) A new method of oocyte separation and preservation for fish reproduction studies. Fish Bull NOAA 91:165-170

Mäemets A (1977) Eesti NSV järved ja nende kaitse (in Estonian). Valgus, Tallinn

Marshall DJ, Bonduriansky R, Bussière LF (2008) Offspring size variation within broods as a bet-hedging strategy in unpredictable environments. Ecology 89:2506-2517. doi:10.1890/070267.1

McCormick MI (2006) Mothers matter: crowding leads to stressed mothers and smaller offspring in marine fish. Ecology 87:1104 1109. doi:10.1890/0012-9658(2006)87[1104:mmclts]2.0.co;2

Moran MD (2003) Arguments for rejecting the sequential Bonferroni in ecological studies. Oikos 100:403-405. doi:10.1034/j.16000706.2003.12010.x

Morrongiello JR, Bond NR, Crook DA, Wong BBM (2012) Spatial variation in egg size and egg number reflects trade-offs and bethedging in a freshwater fish. J Anim Ecol 81:806-817. doi:10. 1111/j.1365-2656.2012.01961.x

Nakagawa S (2004) A farewell to Bonferroni: the problems of low statistical power and publication bias. Behav Ecol 15:1044-1045. doi:10.1093/beheco/arh107

Neja Z (1988) On some problems of reproduction of ruff, Gymnocephalus cernuus (L., 1758) in the Lake Dabie. Acta Ichthyol Piscat 18:33-50

Nguyen HQ, Reinertsen H, Rustad T, Tran TM, Kjorsvik E (2012) Evaluation of egg quality in broodstock cobia Rachycentron canadum L. Aquac Res 43:371-385. doi:10.1111/j.1365-2109. 2011.02840.x

Nissling A, Kryvi H, Vallin L (1994) Variation in egg buoyancy of Baltic cod Gadus morhua and its implications for egg survival in prevailing conditions in the Baltic Sea. Mar Ecol-Prog Ser 110:67-74. doi:10.3354/meps 110067

Ogle DH (1998) A synopsis of the biology and life history of ruffe. J Great Lakes Res 24:170-185. doi:10.1016/S0380-1330(98)70811-1

Ojanguren AF, Reyes-Gavilán FG, Braña F (1996) Effects of egg size on offspring development and fitness in brown trout, Salmo trutta L. Aquaculture 147:9-20. doi:10.1016/s00448486(96)01398-1

Ojaveer H (2003) Sand goby, Pomatoschistus minutus (Pallas). In: Ojaveer E, Pihu E, Saat T (eds) Fishes of Estonia. Estonian Academy Publishers, Tallinn, pp 329-333

Ouellet P, Lambert Y, Berube I (2001) Cod egg characteristics and viability in relation to low temperature and maternal nutritional condition. ICES J Mar Sci 58:672-686. doi:10.1006/jmsc.2001.1065

Perneger TV (1998) What's wrong with Bonferroni adjustments. Brit Med J 316:1236-1238

Pratt DM, Blust WH, Selgeby JH (1992) Ruffe, Gymnocephalus cernuus: newly introduced in North America. Can J Fish Aquat Sci 49:1616-1618. doi:10.1139/f92-179

Quinn TP, Seamons TR, Vollestad LA, Duffy E (2011) Effects of growth and reproductive history on the egg size-fecundity tradeoff in steelhead. Trans Am Fish Soc 140:45-51. doi:10.1080/ 00028487.2010 .550244

Régnier T, Bolliet V, Gaudin P, Labonne J (2013) Bigger is not always better: egg size influences survival throughout incubation in brown trout (Salmo trutta). Ecol Freshw Fish 22:169-177. doi:10.1111/eff.12018

Richter H, McDermott JG (1990) The staining of fish otoliths for age determination. J Fish Biol 36:773-779. doi:10.1111/j.1095-8649. 1990.tb04331.x

Rideout RM, Trippel EA, Litvak MK (2005) Effects of egg size, food supply and spawning time on early life history success of haddock Melanogrammus aeglefinus. Mar Ecol-Prog Ser 285:169-180. doi:10.3354/meps285169

Riesch R, Plath M, Schlupp I (2012) The offspring size/fecundity trade-off and female fitness in the Atlantic molly (Poecilia mexicana, Poeciliidae). Environ Biol Fish 94:457-463. doi:10. 1007/s10641-011-9960-6

Saat T, Kirsipuu A, Turovski A (2003) Ruffe, Gymnocephalus cernuus (L.). In: Ojaveer E, Pihu E, Saat T (eds) Fishes of Estonia. Estonian Academy Publishers, Tallinn, pp 307-313

Segers FHID, Taborsky B (2011) Egg size and food abundance interactively affect juvenile growth and behaviour. Funct Ecol 25:166-176. doi:10.1111/j.1365-2435.2010.01790.x

Segers FHID, Taborsky B (2012) Juvenile exposure to predator cues induces a larger egg size in fish. Proc Roy Soc B Biol Sci 279:1241-1248. doi:10.1098/rspb.2011.1290

Simon TP, Vondruska JT (1991) Larval identification of the ruffe, Gymnocepahlus cernuus (Linnaeus) (Percidae: Percini), in the St. Louis River Estuary, Lake Superior drainage basin, Minnesota. Can J Zool 69:436-442. doi:10.1139/z91-068

Smith CC, Fretwell SD (1974) The optimal balance between size and number of offspring. Am Nat 108:499-506. doi:10.1086/282929

Sogard SM (1997) Size-selective mortality in the juvenile stage of teleost fishes: a review. Bull Mar Sci 60:1129-1157

Solemdal P (1967) The effect of salinity on buoyancy, size and development of flounder eggs. Sarsia 29:431-442. doi:10.1080/ 00364827.1967.10411098

Srivastava RK, Brown JA (1991) The biochemical characteristics and hatching performance of cultured and wild Atlantic salmon (Salmo salar) eggs. Can J Fish Aquat Sci 69:2436-2441. doi:10. 1139/z91-342

Thorsen A, Kjesbu OS, Fyhndr HJ, Solemdal P (1996) Physiological mechanisms of buoyancy in eggs from brackish water cod. J Fish Biol 48:457-477. doi:10.1111/j.1095-8649.1996.tb01440.x

Tibblin P, Koch-Schmidt P, Larsson P, Stenroth P (2012) Effects of salinity on growth and mortality of migratory and resident forms of Eurasian perch in the Baltic Sea. Ecol Freshw Fish 21:200-206. doi:10.1111/j.1600-0633.2011.00537.x

Vetemaa M, Saat T (1996) Effects of salinity on the development of fresh-water and brackish-water ruffe Gymnocephalus cernuus (L.) embryos. Ann Zool Fenn 33:687-691

Wallace JC, Aasjord D (1984) An investigation of the consequences of egg size for the culture of Arctic charr, Salvelinus alpinus (L.). J Fish Biol 24:427-435. doi:10.1111/j.1095-8649.1984. tb04813.x

Winfield IJ, Adams CA, Fletcher JM (1996) Recent introductions of the ruffe (Gymnocephalus cernuus) to three United Kingdom lakes containing Coregonus species. Ann Zool Fenn 33:459-466

Zloch I, Sapota MR (2010) Trophic interactions between preadult and adult Pomatoschistus minutus and Pomatoschistus microps and young Platichthys flesus occurring in inshore waters of the Gulf of Gdansk (Southern Baltic). Oceanol Hydrobiol Stud 39:37-53. doi:10.2478/v10009-010-0018-4 